International Journal of Social Science and Economic Research

ISSN: $2455-8834$

Volume: 05, Issue: 02 "February 2020"

\title{
PREVALENCE OF DEPRESSION AMONG OLDER CLERGY FROM SELECTED MAINLINE CHURCHES IN NAIROBI, KENYA
}

\author{
Ruth Omungo; Michael Kihara, PhD; Timothy Wachira, $\mathrm{PhD}$ \\ Daystar University, Kenya \\ DOI: 10.46609/IJSSER.2020.v05i02.009 URL: https://doi.org/10.46609/IJSSER.2020.v05i02.009
}

\begin{abstract}
The aim of the present study was to find out the prevalence of depression among older clergy aged sixty years. Clergy depression is a psychological aberration that affects clergy due to challenges in coping with stressful vocational experiences. For older clergy, depression is deemed to arise due several factors, such as traumatic experiences in life, declining health, weakened social networks, and precarious financial situations. Stress-induced depression can occur as a temporary response to a traumatic event or it can be a chronic long-lasting condition. Older people are more vulnerable to experiencing such stressful events. However, little empirical work had been done to assess the intensity and severity of depression among older clergy. Ignorance on this matter left us ill-prepared to consider therapeutic interventions that could help older clergy deal with mild and moderate depression. Targeted in the present study were a convenience sample of 160 respondents, drawn from four mainline, Christian denominations, namely, the Anglican Church of Kenya (ACK), Africa Inland Church (AIC), Presbyterian Church of East Africa (PCEA) and Methodist Church of Kenya (MCK). The Becker's Depression Index was used to estimate the level of depression among respondents. According to the findings, most respondents $52 \%(n=83)$ had either mild or moderate depression. About 5 percent of respondents $(n=83)$ had chronic depression. In contingency analysis the frequency of financial support to older clergy emerged as the sole significant factor of depression. Financial difficulties faced by respondents before retirement, largely due to perceived low compensation, and fears of income security post-retirement shape the intensity and levels of depression among older clergy in Nairobi. The findings have generated knowledge about the risk factors for depression among older clergy, evidence and information that would be useful in clinical settings involving depression in older people.
\end{abstract}

Keywords: Older clergy, depression, financial situation 


\section{International Journal of Social Science and Economic Research}

ISSN: $2455-8834$

Volume: 05, Issue: 02 "February 2020"

\subsection{INTRODUCTION AND BACKGROUND}

The occupation of clergy is unique. Its special role strains occur due to a perception by clergy that God has called them to serve, an inner conviction that their work is a divine mandate, which obliges them to undertake their work diligently and devotedly (Moon, 2004). This sense of divine calling makes clergy perceive their work as of higher value than other occupations (Praoeschold, et al, 2013). The sense of divine calling often leaves many of them wondering if they are doing their work to the satisfaction of the one who has called them. This belief can impose on them high expectations about their work, which can lead to exert themselves to work, even when sick, tired, or feeling depressed. For most professions, normal workload is 40 hours per week. But for clergy, work hours are between 55 and 75 hours. This onerous schedule causes them fatigue. Clergy face huge demands by their congregations, and society views them as people called to serve unreservedly. Overall, clergy face considerable occupational challenges, which predisposes them to depression (Praoeschold, et al, 2013).

The routine work of clergy exposes them to several stressful situations. In many places in the world, clergy are the first responders to crises in society. Typically, they handle funeral arrangements, marital conflicts, and personal crises in the lives of parishioners and community members. They are, therefore, recognized as frontline mental health workers (Oppenheimer et al. 2004). For clergy, occupation stress can be overwhelming because they are often called upon to handle pleasant and sombre emotional events at once. For example, a cleric could be joining a couple wedding and immediately after conducting a funeral. Regulating these two emotions can be stressful (Payne, 2009). The sharp shift from an emotional high to an emotional low predisposes clergy to depression.

During crisis, people seek clergy for help more than they do other helping professionals (Wang, 2003). For example, in the US after the September $11^{\text {th }} 2001$ twin towers bombing, $60 \%$ of people affected by the event sought help from a spiritual leader, compared to $45 \%$ of all the respondents who sought help from their physician, and $40 \%$ who would sought help from a mental health care professional (Milstein, 2003). According to Milstein (2003), people in crisis do not prefer to see clergy because they are unaware of alternative mental health care resources. Instead, they do so because they likely to be more familiar with clergy, and because they find discussing personal problems with clergy easier and less stigmatizing. For many clergy, stories shared by people in crisis can be emotionally overwhelming, leaving clergy themselves in need of therapeutic help. Usually, clergy struggle getting such help, which leaves them susceptible to depression (Praeschold, 2014; Barna, 2016).

The occupational difficulties facing older clergy merit attention. Often, older clergy have been in ministry for a long time. They have thus faced diverse personal and occupational challenges than 
International Journal of Social Science and Economic Research

ISSN: $2455-8834$

Volume: 05, Issue: 02 "February 2020"

younger clergy. They have likely moved several times from one parish to another, encountering not a few challenges of transition. They have faced leadership and related occupational conflicts more than younger clergy have. Importantly, too, they have diminished health, and are likely to be suffering from chronic or debilitating illnesses. Given their advanced age, they are likely to have weaker social networks, with many of their friends or colleagues either likely to have passed on or suffering from debilitating illnesses. Facing retirement, older clergy are likely to have dwindling or precarious financial streams (Wilson, 2007). In the Kenyan context too, older clergy face a dilemma when considering whether to seek psychological help because younger clergy consider them as models and seek them for guidance. As such, older clergy needing therapeutic help find it hard to get help. As it happens, not much scholarly attention has been given to the psychological problems facing older clergy in Kenya. Few, if any study, has investigated the mental health of clergy in Kenya.

Accordingly, the present study grows out of this deficit in knowledge. It seeks to understand the scope, intensity, and factors of depression among older clergy in several mainline churches in Kenya. In doing so, the study generates insights that enriches our understanding of the risk factors for depression among older clergy. Insights obtained from the study could be useful in clinical settings involving depression affecting older people.

\subsection{RESEARCH METHODOLOGY}

The present study aimed to establish the prevalence of depression among older clergy. Targeted were $(n=160)$ clergy who were at least sixty years, and the respondents were drawn from four selected Christian denominations, namely, Anglican Church of Kenya (ACK) Africa Inland Church (AIC), Presbyterian Church of East Africa (PCEA) and Methodist Church of Kenya (MCK). These four denominations form the oldest mainline denominations in the country having been initiated by missionaries in 1844 (ACK), 1862 (MCK), 1891 PCEA and 1895 (AIC) (Nthamburi, 1991, Baur, 1994). The respondents were selected using convenience sampling, and the distribution of respondents was as follows: ACK ( $n=55)$, PCE AIC (51), MCK ( $n=32)$, and AIC $(n=20)$. Since older clergy, who are at least 60 years old, are few, the researcher included in the study any of them who met the age threshold.

A researcher-generated questionnaire capturing the sociodemographic data of the clergy was used. The data sought included demographic information, quality of financial support, questions related to the retirement of clergy, and the health condition of clergy. The Beck Depression Index (BDI), a 21-item tool, was used to estimate the levels of depression among participants. The BDI measures the intensity, severity, and depth of depression in people. It assesses mood, pessimism, sense of failure, self-dissatisfaction, guilt, punishment, self-dislike, self-accusation, suicidal ideas, crying, irritability, social withdrawal, body image, work difficulties, insomnia, 


\section{International Journal of Social Science and Economic Research}

ISSN: $2455-8834$

Volume: 05, Issue: 02 "February 2020"

fatigue, appetite, weight loss, bodily preoccupation, and loss of libido (Polgar, 2014). The following guidelines are recommended for the interpretation of scores: 0 - 9 minimal depressive symptoms, 10 - 16 mild depression, 17 - 29 moderate depression, and 30 to 63 severe depression (Azurai, 2015). ${ }^{1}$ The BDI has been adopted for use in Kenya. Presented below are the results of the study.

\subsection{RESULTS}

\subsection{General Prevalence of Depression}

Based on the Beck Depression Index categorization, $43.2 \%$ of the retired clergy, the largest single category, had only minimal depression. However, about 1 in 2 respondents had either moderate $(n=45,28 \%)$ or mild depression $(n=38,24 \%)$. About $5.3 \%(n=8)$ of retired clergy had severe depression. These figures are comparable to findings of existing studies. For instance, a community-based study done in India involving a sample of 70 to 7,150 elderly subjects found a prevalence for depression of about 35\%, ranging from a low of $8.9 \%$ to a high of $62.16 \%$. But a clinic-based studies involving 50 to 5,260 participants report prevalence rates ranging from $42.4 \%$ to $72 \%$ (Grover, 2015).

Yet, existing studies suggest depression affects many older people. A study done in homes for the elderly in Nepal found the prevalence of depression was $47.33 \%$ of population had depression. Among the depressed population, $70.42 \%$ had mild depression and $29.58 \%$ had severe depression. Studies done in South Africa on older people found depression levels comparable to those observed in the present study. A study done to assess the prevalence of depression among older adults attending a primary health care clinic in the Ethekwini District in Kwa-Zulu Natal found that $40 \%$ of patients screened positive for depression (Padayachey, 2017). Other studies done in South Africa find high depression rates. A study conducted among older adults living in a low resource, peri-urban area in South Africa, reported a 50\% prevalence of depressive symptoms (Narainsamy, 2015). And another study done in South Africa showed that clinically significant depressive symptoms are present in 9.8-39\% of community-dwelling older adults. A 12-month South African depression prevalent cases, 26\% were classified as severe, $31 \%$ as moderate, and $43 \%$ as mild (Herman, 2009).

Studies that assess the prevalence of depression among clergy are scarce. The few studies that exist suggest depression is a serious problem for clergy. Using the Symptom Checklist-90Revised, for instance, researchers in the US found that $41 \%$ of 44 Roman Catholic clergy exhibited depressive symptoms (Knox et al., 2007). A similar study in the US, by the Fuller

\footnotetext{
${ }^{1}$ BDI's psychometric properties including its test-retest reliability and internal consistency have been supported by
} research (Beck, Steer, Ball, \& Ranieri, 1996). 


\section{International Journal of Social Science and Economic Research}

ISSN: $2455-8834$

Volume: 05, Issue: 02 "February 2020"

Institute on American pastors, reveal that $35 \%$ of pastors battle depression or fear of inadequacy while $57 \%$ of pastors feel discouraged, stressed, and fatigued (Gaultiere, 2017). A survey of 1050 pastors, during a pastors' conferences in California, found that $70 \%$ of pastors constantly fight depression (Krejcir, 2007). Other existing studies suggest clergy, as people helpers, will have abnormal stress, a predicate for depressive symptoms (Canel, 2011). For this reason, it was fitting to explore the determinants of depression among older clergy in Nairobi.

\subsection{Determinants of Depression Among Clergy in Nairobi}

Examined was the effect of demographic factors and retirement-related issues. Together, 11 factors were in focus, and their effect on depression levels was ascertained using contingency analysis and a one-way ANOVA. The results are discussed in the following section.

\section{Effect of Demographic Variables on Depression Levels among Older Clergy}

Table 1: Depiction of Prevalence of Depression Based on Demographic Variables

\begin{tabular}{|c|c|c|c|c|c|c|c|}
\hline & & $\begin{array}{l}\text { Minimal } \\
\text { depression }\end{array}$ & $\begin{array}{l}\text { Mild } \\
\text { depression }\end{array}$ & $\begin{array}{l}\text { Moderate } \\
\text { depression }\end{array}$ & $\begin{array}{l}\text { Severe } \\
\text { depression }\end{array}$ & & $\begin{array}{l}\text { chi- } \\
\text { square } \\
\text { test }\end{array}$ \\
\hline \multirow{2}{*}{ Gender } & Male & $44.5 \%$ & $26.4 \%$ & $23.6 \%$ & $5.5 \%$ & $100.0 \%$ & \multirow[t]{3}{*}{0.192} \\
\hline & Female & $36.4 \%$ & $13.6 \%$ & $45.5 \%$ & $4.5 \%$ & $100.0 \%$ & \\
\hline Total & & $43.2 \%$ & $24.2 \%$ & $27.3 \%$ & $5.3 \%$ & $100.0 \%$ & \\
\hline \multirow{4}{*}{$\begin{array}{l}\text { Marital } \\
\text { status }\end{array}$} & Single & $75.0 \%$ & & $25.0 \%$ & & $100.0 \%$ & \multirow[t]{5}{*}{0.500} \\
\hline & Married & $39.4 \%$ & $27.5 \%$ & $27.5 \%$ & $5.5 \%$ & $100.0 \%$ & \\
\hline & Widowed & $50.0 \%$ & $16.7 \%$ & $25.0 \%$ & $8.3 \%$ & $100.0 \%$ & \\
\hline & Divorced & & & $100.0 \%$ & & $100.0 \%$ & \\
\hline Total & & $42.3 \%$ & $24.6 \%$ & $27.7 \%$ & $5.4 \%$ & $100.0 \%$ & \\
\hline \multirow{5}{*}{$\begin{array}{l}\text { Education } \\
\text { level }\end{array}$} & Primary & & $100.0 \%$ & & & $100.0 \%$ & \multirow[t]{6}{*}{0.183} \\
\hline & Secondary & $55.6 \%$ & $11.1 \%$ & $22.2 \%$ & $11.1 \%$ & $100.0 \%$ & \\
\hline & $\begin{array}{l}\text { College } \\
\text { Diploma }\end{array}$ & $36.2 \%$ & $21.3 \%$ & $40.4 \%$ & $2.1 \%$ & $100.0 \%$ & \\
\hline & $\begin{array}{l}\text { College } \\
\text { Degree }\end{array}$ & $40.4 \%$ & $25.5 \%$ & $23.4 \%$ & $10.6 \%$ & $100.0 \%$ & \\
\hline & $\begin{array}{l}\text { Post } \\
\text { Graduate } \\
\text { Degree }\end{array}$ & $57.7 \%$ & $26.9 \%$ & $15.4 \%$ & & $100.0 \%$ & \\
\hline Total & & $43.1 \%$ & $23.8 \%$ & $27.7 \%$ & $5.4 \%$ & $100.0 \%$ & \\
\hline
\end{tabular}




\section{International Journal of Social Science and Economic Research}

ISSN: $2455-8834$

Volume: 05, Issue: 02 "February 2020"

According to table 1, there were no significant effects of any of the demographic variables on levels of depression. Other possible factors were related to the process of retirement faced by clergy.

\subsection{Dynamics Related to The Process of Retirement as a Factor in Depression of Older Clergy}

Contingency analysis was done to establish whether events related to the retirement of clergy had a significant effect on the levels of depression observed. The findings are reported immediately.

Table 2: Prevalence of Depression among Older Clergy Based on Retirement Duration

\begin{tabular}{|c|c|c|c|c|c|c|c|}
\hline & & $\begin{array}{l}\text { Minimal } \\
\text { depression }\end{array}$ & $\begin{array}{l}\text { Mild } \\
\text { depression }\end{array}$ & $\begin{array}{l}\text { Moderate } \\
\text { depression }\end{array}$ & $\begin{array}{l}\text { Severe } \\
\text { depression }\end{array}$ & & $\begin{array}{c}\text { chi- } \\
\text { square } \\
\text { test }\end{array}$ \\
\hline \multirow{5}{*}{$\begin{array}{l}\text { When do } \\
\text { you expect } \\
\text { to retire }\end{array}$} & $1-2$ years & $28.6 \%$ & $28.6 \%$ & $38.1 \%$ & $4.8 \%$ & $100.0 \%$ & \multirow[t]{6}{*}{0.537} \\
\hline & 3-4 years & $44.8 \%$ & $20.7 \%$ & $27.6 \%$ & $6.9 \%$ & $100.0 \%$ & \\
\hline & 5 years & & $37.5 \%$ & $50.0 \%$ & $12.5 \%$ & $100.0 \%$ & \\
\hline & $\begin{array}{l}\text { over } 5 \\
\text { years }\end{array}$ & $57.1 \%$ & $28.6 \%$ & $14.3 \%$ & & $100.0 \%$ & \\
\hline & $\begin{array}{l}\text { I dont } \\
\text { know }\end{array}$ & $40.0 \%$ & $20.0 \%$ & $40.0 \%$ & & $100.0 \%$ & \\
\hline Total & & $37.7 \%$ & $26.0 \%$ & $31.2 \%$ & $5.2 \%$ & $100.0 \%$ & \\
\hline \multirow{3}{*}{$\begin{array}{l}\text { When did } \\
\text { you retire } \\
\text { as a pastor }\end{array}$} & $1-5$ years & $50.0 \%$ & $17.6 \%$ & $26.5 \%$ & $5.9 \%$ & $100.0 \%$ & \multirow[t]{4}{*}{0.816} \\
\hline & 6-10 years & $53.8 \%$ & $30.8 \%$ & $7.7 \%$ & $7.7 \%$ & $100.0 \%$ & \\
\hline & $\begin{array}{l}\text { Over } 10 \\
\text { years }\end{array}$ & $50.0 \%$ & $25.0 \%$ & $25.0 \%$ & & $100.0 \%$ & \\
\hline Total & & $50.9 \%$ & $21.8 \%$ & $21.8 \%$ & $5.5 \%$ & $100.0 \%$ & \\
\hline \multirow[t]{4}{*}{ Why retire } & $\begin{array}{l}\text { Reached } \\
\text { statutory } \\
\text { age }\end{array}$ & $47.9 \%$ & $25.0 \%$ & $20.8 \%$ & $6.3 \%$ & $100.0 \%$ & \multirow[t]{4}{*}{0.860} \\
\hline & $\begin{array}{l}\text { On } \\
\text { medical } \\
\text { ground }\end{array}$ & $33.3 \%$ & & $66.7 \%$ & & $100.0 \%$ & \\
\hline & $\begin{array}{l}\text { Reasons } \\
\text { beyond } \\
\text { my } \\
\text { control }\end{array}$ & $100.0 \%$ & & & & $100.0 \%$ & \\
\hline & $\begin{array}{l}\text { Personal } \\
\text { choice }\end{array}$ & $100.0 \%$ & & & & $100.0 \%$ & \\
\hline
\end{tabular}


International Journal of Social Science and Economic Research

ISSN: $2455-8834$

Volume: 05, Issue: 02 "February 2020"

\begin{tabular}{llllllll}
\hline & Others & $100.0 \%$ & & & & $100.0 \%$ \\
\hline Total & & $50.0 \%$ & $22.2 \%$ & $22.2 \%$ & $5.6 \%$ & $100.0 \%$ & \\
\hline How far \\
ahead did \\
$\begin{array}{l}\text { you know } \\
\text { you would } \\
\text { retire? }\end{array}$ & $\begin{array}{l}\text { Years } \\
\text { ahead }\end{array}$ & $48.9 \%$ & $24.4 \%$ & $22.2 \%$ & $4.4 \%$ & $100.0 \%$ & 0.830 \\
\cline { 2 - 6 } & $\begin{array}{l}\text { Months } \\
\text { ahead }\end{array}$ & $57.1 \%$ & $14.3 \%$ & $14.3 \%$ & $14.3 \%$ & $100.0 \%$ & \\
\cline { 2 - 6 } & $\begin{array}{l}\text { Less than } \\
\text { a week } \\
\text { ahead }\end{array}$ & $66.7 \%$ & & $33.3 \%$ & & $100.0 \%$ & \\
\hline Total & & & & & & \\
\hline
\end{tabular}

According to table 2, none of the variables related to the retirement of respondents had a significant effect on the level of depression observed among clergy. This implies the retirement process is not a stressful event for respondents. In other words, changes occasioned by retirement did not constitute the significant life changes that have been associated with stress and depression.

Questions about the financial security of respondents was the other probable factor of depression among respondents. The variables deemed to produce an effect were whether clergy received retirement benefits and how often they did so, if they did.

Table 3: Prevalence of Depression among Older Clergy Based on Retirement Benefit

\begin{tabular}{|c|c|c|c|c|c|c|c|}
\hline & & $\begin{array}{l}\text { Minimal } \\
\text { depression }\end{array}$ & $\begin{array}{l}\text { Mild } \\
\text { depression }\end{array}$ & $\begin{array}{l}\text { Moderate } \\
\text { depression }\end{array}$ & $\begin{array}{l}\text { Severe } \\
\text { depression }\end{array}$ & & $\begin{array}{c}\text { chi- } \\
\text { square } \\
\text { test } \\
\end{array}$ \\
\hline \multirow{3}{*}{$\begin{array}{l}\text { Received } \\
\text { any } \\
\text { retirement } \\
\text { benefits }\end{array}$} & Church & $50.0 \%$ & $25.0 \%$ & & $25.0 \%$ & $100.0 \%$ & \multirow[t]{4}{*}{0.550} \\
\hline & Insurance & $50.0 \%$ & $20.0 \%$ & $25.0 \%$ & $5.0 \%$ & $100.0 \%$ & \\
\hline & Others & $53.8 \%$ & $15.4 \%$ & $30.8 \%$ & & $100.0 \%$ & \\
\hline Total & & $51.4 \%$ & $18.9 \%$ & $24.3 \%$ & $5.4 \%$ & $100.0 \%$ & \\
\hline \multirow{4}{*}{$\begin{array}{l}\text { How often } \\
\text { do you } \\
\text { receive } \\
\text { benefits }\end{array}$} & Monthly & $76.9 \%$ & $23.1 \%$ & & & $100.0 \%$ & \multirow[t]{4}{*}{0.022} \\
\hline & Annual & $16.7 \%$ & $50.0 \%$ & $33.3 \%$ & & $100.0 \%$ & \\
\hline & $\begin{array}{l}\text { After } \\
\text { several } \\
\text { regular } \\
\text { months }\end{array}$ & $40.0 \%$ & & $40.0 \%$ & $20.0 \%$ & $100.0 \%$ & \\
\hline & $\begin{array}{l}\text { After } \\
\text { several } \\
\text { irregular } \\
\text { months }\end{array}$ & $50.0 \%$ & $25.0 \%$ & $25.0 \%$ & & $100.0 \%$ & \\
\hline
\end{tabular}




\section{International Journal of Social Science and Economic Research}

ISSN: $2455-8834$

Volume: 05, Issue: 02 "February 2020"

According to table 4.4. the frequency with which respondents received financial support was a significant factor in explaining the levels of depression among them. Below are personal testimonies gathered during interviews with older clergy in connection to their experiences on financial constraints.

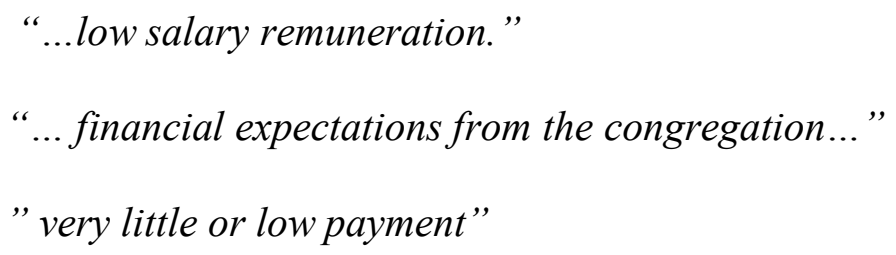

According to the literature, most older people in Africa are financially ill-prepared to be selfreliant in old age (Nicholson, 2004). Likewise, a Duke study observed that a common cause of depression among clergy is a precarious financial position, which gains salience because many of them are under remunerated (Enos, 2008). As older clergy contemplate retirement, they face financial stress, the fear of being unable to maintain their erstwhile standard of life (Sincero, 2012).

\subsection{DISCUSSION}

Clergy depression emanates from financial stress related to difficulties related to their work. The respondents felt that their pay was low, which could be interpreted in the context of their heavy workload and undue pressure from congregants for financial support (Enos, 2008). Additionally, the respondents were fearful that a life in retirement would be hard, given their belief that their sources of income were either uncertain or unreliable. In other words, clergy were doubtful about whether they would receive post-retirement benefits or the frequency with which they would receive them. They suffered financial stress and anxiety because of this, and this subsequently manifested as mild or moderate depression. The depression levels of respondents were high, with about 50 percent of them eligible to participate in therapeutic interventions, such as mindfulness-based cognitive therapy self-help intervention for anxiety and depression.

The findings have shown that demographic factors, such as gender, education, and marital status are not explanatory factors in the depression faced by older clergy. Likewise, the findings have shown that questions related to retirement of clergy, such as contemplating retirement, or the circumstances of doing so, do not seem to contribute to the anxiety of clergy. Importantly, even the health situation of respondents, assessed by whether respondents were on mediation, was not a factor in the depression levels of older clergy. The present study has however established that questions about the financial situation of clergy, including the pressure of supporting needy congregants financially as well anxiety about maintaining their quality of life post-retirement, were predisposing factors of depression among elderly clergy. This means that analysing the 
International Journal of Social Science and Economic Research

ISSN: $2455-8834$

Volume: 05, Issue: 02 "February 2020"

anxiety levels of respondents, especially about questions related to the processes of retirement, including retirement benefits would be fruitful place to begin understanding the depression levels of respondents. Thus, the study has provided useful background information that can inform interventions aimed to deliver therapeutic support to older clergy.

\subsection{CONCLUSION}

The scope and intensity of BDI scores for older clergy suggests this social category merits psychological interventions. About 50\% of clergy suffered from either mild or moderate depression, with about 5 per cent of them suffering from chronic depression. As such, there is need for urgent interventions to help older clergy deal with depression and stem its intensity. In this vein, the usefulness of the MBCT, which has been shown as effective in tackling mild/moderate depression, can be a useful intervention for older clergy. The findings also suggests extra work is needed to use a probability sample on a wider target population of older clergy in Nairobi.

\section{REFERENCES}

Azulai, A. \& Walsh, A. (2015). Screening for geriatric depression in residential care facilities: a systematic narrative review. Journal of Gerontological Social Work, 58(1), 20-45.

Baur, John (1994) 2000 Years of Christianity in Africa Nairobi, Kenya: Paulines Publications Africa.

Canel CD, Cui Y, Lauridsen E (2011) Cross-cultural validation of the beck depression inventoryii across U.S. and Turkish samples. Measurement and Evaluation in Counselling and Development 44(2), 77-91.

Gunaratana, H. (2002). Mindfulness in plain English. Boston: Wisdom Publications

Grover Sandeep, Malhotra Nidhi (2015). Depression in elderly: A review of Indian research Journal of Geriatric Mental Health. 2 (1) 4-15.

Herman, A. A., Stein, D. J., Seedat, S., Heeringa, S. G., Moomal, H., \& Williams, D. R. (2009). The South African Stress and Health (SASH) study: 12-month and lifetime prevalence of common mental disorders. South African medical journal 99(5 Pt 2), 339-344.

Knox, Sarah; Virginia, Stephen G.; and Smith, Jacquelyn (2007). Pilot Study of Psychopathology Among Roman Catholic Secular Clergy. Journal of Pastoral Psychology, 5(3) 297- 306. 
International Journal of Social Science and Economic Research

ISSN: $2455-8834$

Volume: 05, Issue: 02 "February 2020"

Krejcir R. J. (2007). What is Going on with the Pastors in America? Francis A. Schaeffer Institute of Church Leadership Development Retrieved on 8 June 2016 from http://www.truespirituality.org/.

Milstein, G. (2003). Clergy and psychiatrists: Opportunities for expert dialogue. Psychiatric Times, 20(3), 2. Retrieved on 10 August 2017from http://www.psychiatrictimes.com/display/article/10168/47231?

Moon, Gary W. and David G. Benner, eds. (2004), Spiritual Direction and The Care of Souls: A Guide to Christian Approaches and Practices. Downers Grove, Ill: InterVarsityPress,

Narainsamy, J., Chips, J., \& Cassim, B. (2015). Depressive symptoms in community-dwelling persons aged $\geq 60$ years in Inanda, Ntuzuma and KwaMashu in Thekwini, KwaZuluNatal. South Africa Journal of Psychology, 21(1), 13-18.

Openheimer, J. E., Flannerly, K. J.\& Weaver, A. J. (2004). A Comparative analysis of psychological literature on collaboration between clergy and mental health professionals - perspectives from secular nd religious journals: 1970-1999. Pastoral Psychology, 53(2) 153-162.

Payne, J. S. (2009). Variations in pastors' perceptions of the etiology of depression by race and religious affiliation. Community Mental Health Journal, 45(5), 355-365.

Proeschold-Bell, R., Miles, A., Toth, M., Adams, C., Smith, B., \& Toole, D. (2013). Using effort-reward imbalance theory to understand high rates of depression and depression among clergy. The journal of Primary Prevention, 34(6), 439-453. DOI: 10.1007/s10935013-0321-4

Sincero, S. (2012). Stress and cognitive appraisal. Retrieved from https://explorable.com/stressand-cognitive-appraisal.

Nthamburi, Zablon editor (1991). From Mission to Church: A Handbook of Christianity in East Africa, Uzima Press, Nairobi Kenya.

Wang, P. S., Berglund, P. A., \& Kessler, R. C. (2003). Patterns and correlates of contacting clergy for mental disorders in the United States. Health Services Research, 38(2), 647673

Wilson, K., Mottram, P., \& Sixsmith, A. (2007). Depression symptoms in the very old living alone: prevalence, incidence and risk factors. International Journal of Geriatric Psychiatry, 22(4), 361-366. 